\title{
Particularistic and System Trust in Family Businesses: The Role of Family Influence
}

\begin{abstract}
Research on how trust develops and why it matters in family businesses is in development. Our study investigates the emergence and evolution of trust in family business leaders. Drawing on the New Systems Theory, we also examine the impact of family influence on trust. Multiple semi-structured interviews were performed in three Chinese family businesses. Results suggest that relationship-based particularistic trust prevails at the start-up stage because of the void of governance mechanisms. As businesses grow, particularistic trust gradually gives way to institution-based system trust. Evidence further indicates high family influence catalyses particularistic trust initially and restricts system trust subsequently.
\end{abstract}

Key Words: particularistic trust, system trust, new systems theory, family influence, decision premise

\section{Introduction}

The business environment has become increasingly competitive. In this relentlessly competitive environment, family businesses have to continuously adjust their strategies, balance their idiosyncratic family and business needs, and align their operations with the changing environment to tackle intense competition (Eisenhardt and Martin 2000; Chrisman, Chua, De Massis, Frattini, and Wright 2015). Leaders who are able to garner trust from their subordinates, regardless of the changing environment, may lead their businesses toward success. In contrast, when leaders are incompetent in gathering trust, cohesiveness of the firm deteriorates (Sundaramurthy 2008), and the owning family loses its control (Davis, Allen, and Hayes 2010).

The importance of trust in leader has been recognised for more than five decades (Argyris 1962). The value of trust in leader, its antecedents as well as the behaviour and performance outcomes 
have been examined in the disciplines of organisational psychology, public administration, leadership, and others (Dirks and Ferrin 2002; Burke, Sims, Lazzara, and Salas 2007). Since the late 1990s, trust has even turned into a theme of research on its own (Dirks and Ferrin 2002). Nevertheless, irrespective of the considerable development, trust has yet been integrated into the mainstream family business research (Eddleston, Chrisman, Steier, and Chua 2010). In fact, research on trust has not been adequately implemented in the family business context.

Researchers argue that family businesses differ from their non-family counterparts because of the intermingling family and business systems (Sirmon and Hitt 2003; Habbershon, Williams, and MacMillan 2003), where both business ownership and management are helmed by the same family (González-Cruz and Cruz-Ros 2016). This determines that family businesses often rely on a form of governance that is family-influenced (Allen, George, and Davis 2018) and communication-based. In this context trust, which is communicatively constructed (Frank, Kessler, Rush, Suess-Reyes, and Weismeier-Sammer 2017), often plays an important role (Sundaramurthy 2008; Shi, Shepherd, and Schmidts 2015; Wang 2016a) and functions as a "lubricant" (Allen et al., 2018) facilitating relationships among family and non-family employees. In fact, family businesses often possess trustrelated advantages (Steier 2001) such as employees' identification with the business, loyalty, and willingness to sacrifice personal interests (Davis, Schoorman, and Donaldson 1997; Davis et al. 2010; De Massis, Frattini, Pizzurno, and Cassia 2015). These are the attributes that non-family businesses seek constantly and have to invest significant resources to achieve. Nevertheless, how is trust and in particular trust in leader constructed in the family business environment? How does trust in leader evolve as the business develops? How does family influence affect trust in the evolution process, since the family represents a distinctive part in this business setting? In the limited studies on trust in family businesses, Sundaramurthy (2008) made an attempt to answer the first two questions in her conceptual paper. Viewing trust as a dynamic concept, she argued that at the initial stage a high level of relationship-based trust often exists. As the business grows, other types of trust such as competence 
trust and system trust emerge. While acknowledging that Sundaramurthy's study explains the initiation and evolution of trust in family businesses, we recognise that how family influence affects trust in the business evolution process is unaddressed. This then becomes the focal point of our paper. Also, in our paper we attempt to empirically examine Sundaramurthy's conclusion.

The current paper investigates how trust in leader in family businesses emerges and evolves and how family influence affects trust in this process. By relying on a qualitative approach, we contribute to the understanding of trust in leader in family businesses in the following important ways. Firstly, the study focuses on the impact of family influence on trust in leader, which has yet to be examined in the family business context. The new systems theory (nST) is adopted as the underpinning theoretical framework (Luhmann 1995, 2013). We examine the impact of family influence on trust via decision premises. Our findings offer a new understanding to the literature by showing the nexus between family influence and trust, and specifically the circumstances under which family influence enables trust construction. Secondly, the study explains why, how, and under what circumstances trust in leader evolves with business development. This result is important, in that most prior studies adopt a static perspective, which may be time-sensitive, context-specific, and bias-ridden. We adopt a dynamic viewpoint (Sundaramurthy 2008) that is conducive to understanding the evolution of trust and the role of family. Finally, this study investigates trust in leader in Chinese family businesses, which leads to more in-depth understanding of China's private sector and its effects on an array of aspects relevant to family business management, including entrepreneurial venturing, social networking, and business sustainability.

The remainder of this paper includes four sections. In the theoretical background section, the literature in relation to trust in leader, particularistic trust and system trust is reviewed. The subsequent research methodology section defines the methodological approach this study adopts and the data collection and analysis procedure. Research results are then presented. This is followed by the 
discussion and conclusion, including the summary of contributions, implications of this study, and directions for future research.

\section{Theoretical Background}

\section{New Systems Theory}

The nST as a theoretical framework recently has been applied to family business research (Von Schlippe and Frank 2013; Frank et al. 2017; Hasenzagl, Hatak, and Frank 2018). The nST was initiated by Luhmann $(1995,2013)$, who argued that a society consists of many separated social systems and each social system is built upon countless meaningful communication. Communication continuously reproduces itself and through continuous juxtapositions of communication, a social system is developed (Mattheis 2012; Frank et al. 2017). While communication forms the core of the theory (Luhmann 1995), the nST emphasises the processes or mechanisms of communication, instead of individual players involved in communication (Von Schlippe and Frank 2013). Thus, the nST can reduce the complexity in understanding a social system, because understanding the rules of the game is often easier than appreciating individuals and their interactions in the system (Frank et al. 2017).

Organisations are social systems. In particular, a family business is a social system that has two interactive components, namely the family and the business (Sharma, Chrisman, and Chua 1996). Luhmann (2013) indicated that organisations are "systems made up of decisions, and capable of completing decision[s] that make them up, through decisions that make them up" (p.32). That is, organisations make decisions based on former decisions, or alternatively, decisions are autopoietic and self-referential. Seidl (2004) pointed out that those decisions that are crucial to organisational operations are often connected and they further become preconditions for a set of future decisions. Simon (1957) introduced an important concept of decision premise, which frames the decision-making process. Decision premises take time to be built up; nevertheless, once established, they constitute a basal and enduring structure for decision-making in organisations (Suess-Reyes 2017). From the nST 
point of view, a family business can be defined as "a communication system incorporating the decision premises shaped by a family" (Frank et al. 2017, p.712). Similarly, a business family can be defined as "a communication system of a self-defined group of the family that is involved in business-related communication and capable of influencing the decision premises in the business" (Suess-Reyes 2017, p.753).

In fact, a number of theoretical frameworks have been taken into account as the theoretical underpinning of the current study, for instance the network theory. Via the lens of the network theory, a family business may be viewed as a bundle of networks and the analysis will focus on how each individual interacts with others in the networks. In the current study's context the nST is more appropriate, since it views organisations as communication-based social systems and centres on what mechanisms enable the business family to influence the family business and what forms the basis for trust in leader.

\section{Family Influence via Decision Premises}

Since the notion was introduced, researchers have employed an array of terms to describe the essence of family influence, including familiness, family capital, family involvement and family control (Habbershon and Williams 1999; Chrisman, Chua and Steier 2005; Hoffman, Hoelscher, and Sorenson 2006; Carnes and Ireland 2013), yet hitherto there is no agreement on what family influence is. When operationalising this notion, a common approach is to evaluate the extent of ownership, management, and control. Frank et al. (2017) argued that family influence in the business "in terms of ownership, management, or control does not necessarily mean that the family exercises its potential influence on the business" (p.715). Families may have their notional influence only on the paperwork, and never genuinely influence business behaviour. Frank et al. (2017) suggested that researchers focus on "the actual family influence via the decision premises the family implements in the business" (p.715) to understand how unconventional family-induced behaviour occurs. In this paper, when family influence 
is concerned, we take into account the influence from the entire business family, including the ownermanager.

Simon (1957) argued that organisations choose decision premises in their own business context. They decide which decision premises they should concentrate on and how much effort they should engage in via the decision premises. The business family is able to "imprint family-specific decision premises" (Frank et al. 2017, p.713) into the firm's communication system. Via these premises, the business family expresses its interests and then reflects them in the firm's communication as well as operations. In their study, Miller and Le Breton-Miller (2005) offered a four-C framework, which implies family influences business via four inter-related decision premises, namely continuity, command, community, and connection. In particular, continuity means that decision-oriented communication within family businesses is recursively associated with business continuity. Transgenerational succession and business longevity are perennial communication topics in family businesses. Moreover, compared to less family-influenced firms, highly family-influenced businesses are more interested in sustaining business ownership and wealth within the business family (Miller, Le Breton-Miller, and Lester 2010). Command infers that autopoietic and self-referential communication within family businesses is often related to authority. Family business executives are powerful individuals and they often "behave in an unorthodox way" (Miller and Le Breton-Miller 2005, p.525), given their ownership of the business and responsibility for the family. Communication in family businesses often reflects these executives' authority. In addition, compared to those in less familyinfluenced firms, executive leaders in highly family-influenced businesses are likely to keep a higher level of autonomy and are more independent from other stakeholders (Miller and Le Breton-Miller 2005; Konig, Kammerlander, and Enders 2013). Community means that autopoietic and self-referential decision-oriented communication is often about the entity that employers intend to establish within their businesses. Employers of family businesses often intend to create a "pseudo-family" (Tan and Fock 2001, p.128), which embraces employees and encourages their commitment. Specifically, executive 
leaders in highly family-influenced businesses are often selective and choose to socialise with a small number of staff members (that is, the more family influence on the business, the narrower its community becomes), as they wish "their personal values and ethics are deeply embedded in their company" (Miller and Le Breton-Miller 2005, p.521) so that the business can be directed by the business family. Finally, connection suggests that decision-oriented communication within family businesses is often about building up social networks. In particular, highly family-influenced firms usually build up social capital and enduring alliances with a small number of stakeholders (that is, the more family influence on the business, the narrower the connection becomes), through which they construct their identities and status in the society (Miller and Le Breton-Miller 2005). Frank et al. (2017) stated that decision premises in family businesses often demonstrate two features: a) they "regulate the influence of the family and institutionalise it", and b) "reduce complexity ... and simplify decision process" (p.714). We argue that the four Cs exhibit the features of decision premises. Continuity, command, community, and connection are communicatively constructed in family businesses and are able to institutionalise family influence. They portray the inherent characteristics of family influence and holistically outline the family-induced nature. They can also be perceived as the "rules of the game" in decision-making, simplifying the decision-making process. The four-C premises take time to construct (Suess-Reyes 2017), but once established, no matter whether the family is directly involved in the decision-making process, it will influence the decision (Frank et al. 2017) via these premises.

\section{Concept of Trust and Levels of Trust}

Family businesses distinguish themselves from their non-family counterparts in that both business ownership and management are held by one family (Chrisman, Chua, and Litz 2004; Allen et al. 2018). As a result, family business governance is often family-influenced and communication-based. Trust 
plays an important role in this context, which can catalyse interactions between leaders and employees. When trust is absent, employees are less likely to engage in constructive behaviour (Allen et al. 2018).

In this study, we examine the trust of employees, including both family and non-family employees, in their leaders. In particular, we choose the owner-manager as our referent of trust. Dirks and Ferrin (2002) found that most studies investigating trust in leader focus on one of the two referents: the direct leader (e.g., supervisor) or the executive leader. The roles of the two leaders differ (Bass 1990). While the direct leader often offers operational supervision, the executive leader acts more strategically. Trust in the direct leader often leads to an employee improving job performance. In contrast, trust in the executive leader often results in an individual's higher organisational commitment and psychological affiliation (cf., Dirks and Ferrin 2002). In this study, our referent of trust is the executive leader. In the small-sized family business context, executive leadership is often taken by the owner-manager. Thus, trust in leader in our study means trust of employees, including both family and non-family employees, in the owner-manager(s).

Trust is a multi-level concept in management research (Sundaramurthy 2008). Researchers recognise that trust exists at the interpersonal level (between different individuals), organisational level (between employees and their organisation), inter-organisational level (between organisations), and society level (between individuals in a society) (Burke et al. 2007; Yamagishi, Cook, and Watabe 1998). In the current study, we position trust at both interpersonal and organisational levels. During an initial business stage, trust in leader is more likely to occur at the interpersonal level (Sundaramurthy 2008), which stems from particularistic ties between the employees and the leader (Luhmann 1979; Tan, Yang, and Veliyath 2009). This trust is relationship-based. When owner-managers continuously communicate and interact with their subordinates, their capability or integrity may evoke the employees' confidence and positive perceptions. Mishra and Spreitzer (1998) in a study of the role of trust in a change process outline four key dimensions of a change agent's trustworthiness, namely competence, reliability, openness, and caring the interests of stakeholders (cf., Croonen 2010). We 
borrow the four dimensions, and argue that from the nST perspective these four dimensions represent the decision premises to relationship-based trust. In family businesses, recursive communication about leaders' competence, reliability, openness, and caring nature occurs. When such communication is generally positive, employees are inclined to trust their leader. The second level of trust is at the organisational level, which often occurs at the business mature stage. Family businesses at this time often demand a higher level of operational consistency and reliability. The foci of communication therefore shift away from the attributes of leaders to the nature of policies and procedures. In this context, an executive leader who is able to develop enabling policies and procedures often harvests trust. Herein transparency and fairness of procedures and policies are crucial (Sundaramurthy 2008). From the nST perspective, transparency and fairness represent the decision premises, and communication at the mature stage is often about transparency and fairness. When such communication is optimistic, employees' institution-based system trust will be evoked (Tan et al. 2009). Here, transparency means that rules and procedures in a family business are open and explicit to employees. This is not easy given the accentuated family interest in business control and the sensitivity of familyinfluenced governance (Miller and Le Breton-Miller 2005). Fairness on the other hand requires leaders to consider their subordinates' diversified interests and design policies and procedures that treat each individual equally (Whitener 1997; Heyden, Blondel, and Carlock 2005).

\section{Family Influence, Particularistic Trust, and System Trust}

During the early stage of family businesses, trust in leader is often derived from interactions between a leader and his/her subordinates (Sundaramurthy 2008), while family influence via the decision premises may catalyse this relationship-based trust. For instance, family influence via the continuity premise means that decision-related communication within family businesses is often about business continuity. This drives businesses to concentrate on developing commercially acceptable products initially and creating customer bases. Leaders therefore are impelled to actively show their competence 
in acquiring resources as well as accesses to tacit knowledge. Employees on the other hand are encouraged to interact with their leaders and share experience and expertise. Such interactions are conducive to relationship construction, enabling each individual 'to 'feel' as well as to 'think' like the other" (Lewicki and Bunker 1996, p.122). Moreover, the communicatively constructed continuity concern may prompt leaders to be open to their subordinates and look after their needs. In such family businesses, employees are willing to contribute for the good of the business, "even to the point of selfsacrifice" (Gersick, Davis, Hampton, and Lansberg 1997, p.3). They are psychologically connected to their leaders. Particularistic trust therefore stems from this close relationship, as a result of leaders' attributes (i.e., decision premises from the nST point of view).

When it grows, a family business demands a higher level of operational reliability and efficiency, which invites systematic regulatory inputs. Relationship-based particularistic trust thus gradually loses its grounding, and gives way to institution-based system trust as the means that governs interpersonal exchanges (Sydow 1998; Sundaramurthy 2008). System trust, by nature, relies on transparency and fairness of policies and procedures (Luhmann 1979; Sundaramurthy 2008). In those family firms when continuity is communicated, executive leaders usually encourage family members to join the firms, or even take senior positions irrespective of their competency. This recruitment, though seeming to have addressed the continuity concern, barely shows any transparency or fairness. Thus, communication on transparency and fairness of policies is likely to be negative, which constrains the development of system trust. In fact, setting up transparent and fair policies in such family businesses is often difficult, since stakeholders are psychologically ambivalent toward policy construction. Owner-managers may encounter psychological deterrents to policy development as it implies relinquishing personal autonomy. Family members worry about loss of family harmony and potential conflicts (Lansberg 1999). Non-family managers, who have served the firm for long, may be reluctant to switch from relationship-based to policy-based management (Lansberg 1999). 
The above sections illustrate the theoretical framework, introduce the concept of trust and levels of trust, and review the literature on the relationship between family influence, particularistic trust, and system trust. The next section describes the research design and the methodology adopted to develop insights into how trust in leader emerges and evolves in family businesses, as well as the role of family influence.

\section{Research Design and Method}

Existing family business research tends to prefer a positivist paradigm and incorporate hypothesis testing based on a quantitative approach (De Massis, Sharma, Chua, and Chrisman 2012). Nevertheless, as discussed earlier, knowledge about the evolution of trust and the impact of family influence on trust in leader is scarce. The absence of conclusive data pushed us to employ alternative research methods (Kontinen and Ojala 2011; Dalpiaz, Tracey, and Phillips 2014). In this study, we embrace a postpositivist ontological position because of its emphasis on investigating and identifying "relationships and non-relationships, respectively, between what we experience, what actually happens, and the underlying mechanisms that produce the events in the world" (Danermark, Ekstron, Jakobsen, and Karlsson 2002, p. 21). We adopt a qualitative strategy by using multiple case studies (Yin 2009) to enable "quality, depth and richness in the findings" (Marshal and Rossman 1999, p. 16) and understand these findings in an authentic context. This strategy also allows us to collect both subjective and objective data to develop rigorous and robust insights into the phenomenon (Reay and Whetten 2011). The inductive approach further leads to a conceptual typology of family influence on trust in family business leaders via decision premises, which is a major outcome of the study.

The study was conducted in China. The Chinese economy still has a great level of complexity with co-existing state-owned, collective-owned, private-owned, and other types of enterprises (Wang 2016b), even after almost four decades of economic reforms. Classified as private firms, family 
businesses receive a low level of legal and institutional protection due to ideological concerns (Tan 2002), thus trust and relational capital play an idiosyncratic role in business operations. On the other hand, the transition that China is undergoing offers opportunities to family businesses (Jiang, Gong, Wang, and Kimble 2016), as reforms in policies, regulations, and legal frameworks encourage entrepreneurial venturing. Investigations in such a transitional environment are interesting, and in particular scrutiny of the emergence and evolution of trust in family businesses.

Though the development of an accurate family business definition is still on-going, researchers generally agree that family businesses refer to those where a family has a substantial impact on business management (De Massis et al. 2015). In this study we defined a family business as a business shaped by a family with family members playing an active role in its decision-making and operations (Frank et al. 2017). Moreover, we decided to incorporate small- and medium-sized enterprisesi in our study. By focusing on companies of a similar size, we avoided the risk of confusing heterogeneity as a result of difference in company size (De Massis et al. 2015). We further sought to obtain a balanced sample combining homogeneity and heterogeneity (cf., Merriam 1988). On the one hand, we selected case companies in two diverse regions in China, namely the eastern coastal province of Jiangsu, which was a first-mover in the rise of China's private economy with well-developed market infrastructure, and the western inland autonomous region of Xinjiang, which was a typical late-comer in China's economic development but arguably rich in nascent opportunities for new and entrepreneurial activities. On the other hand, all case companies engaged in similar business activities, namely, vehicle parts manufacturing, sales and services. By doing this, we took into consideration not only data availability and accessibility but also cross-case comparability.

Studying the evolution of trust in leader required the case company to be in operation for sufficient time as for the evolution to occur and to be captured. Yet, China's private economy only commenced to emerge after 1979, hence, a lack of available and accessible businesses potentially 
eligible for the study, particularly in the less developed region of Xinjiang. As our interviews continued, however, repetition of information emerged and increased, until such repetition became dominant and subsequent emergence of new themes became significantly unlikely (Creswell 1994). This signalled the information saturation (Eisenhardt and Graebner 2007). As a result, the study entailed three cases (see Table 1).

\section{Insert Table 1 here}

We used semi-structured interviews where open-ended questions were asked around the key constructs as defined earlier, which ensured an uninterrupted emphasis on family influence and trust in leader, and allowed interviewees to bring in their own themes and evidence relevant to the study. For example, to understand family influence via the command premise, we asked the interviewees to describe the "standard" way in which instructions and directives were given and received. While most interviewees explained the line of reporting and their position in the line, there were comments on its historical changes as well as the "feeling" about its effectiveness. These were the moments when further discussions were held to explore "how" and "why" (Yin 2009).

To ensure validity of data (Eisenhardt 1989), multiple interviews were conducted for each case company, involving the owner-managers, founders, employees from management and nonmanagement positions, family members and relatives who were involved in the business (see Table 2). Eventually having four to five interviews per case helped us reduce dependence on any one individual, and having the same information gathered from multiple sources helped verify its authenticity. Each interview commenced with a brief introduction explaining the purpose, process and implications of the research. The emphasis then moved on to the family's influence in the business and the interactions between the executive leaders and their followers. The purpose was to identify the origin, evolution, and outcome of trust in leader.

To supplement the insights emerged from interviews, we also utilised personal observations on site during fieldwork. Though few systematic data was produced directly from these observations, they 
somehow provided extra evidence for our understanding of the phenomena under question. Specifically, the factory layout gave an impression of how people were related at workplace; employees' actions and tones that we saw and heard during our site visits also helped us understand communication relationships at the case companies. For example, we noticed that at the main entrance of ED, there was a banner reading "Welcome to ED, your home away from home", which indicated that the company tried to nurture a family-like atmosphere at work that could be related to the family influence on its community premise.

\section{Insert Table 2 here}

Consistent with the inductive methodology of the study, we took an interpretative approach in data analysis, mainly because of the qualitative nature of the study in general, and the descriptive nature of the data in particular (Creswell 1994). Interview recordings were transcribed in Chinese verbatim, and coded for each case for information related to the main constructs (i.e., decision premises, particularistic trust, system trust) and the evolution of them (i.e., initial stage, mature stage). We conducted keyword searching and repeated reading to capture meaning repetitions, which enabled a clustering analysis that grouped together similar meanings in order to yield common themes. The purpose of this approach was also to minimise irrelevant information in the wealth of the collected information and control the possible variance (Wang, Huang, and Tan 2013). Given that the Chinese language is highly contextual, we processed analysis in Chinese in order to retain the true meanings as much as possible, and to avoid the risk of losing them in translation. The coded themes and relevant quotes were then translated into English by both authors independently and then compared to ensure the accuracy. The back translation technique (Harkness 2003) was also used to guarantee the accuracy and credibility of the data translation.

\section{Findings}


In this section, the findings from the case studies are presented. We concentrate on the four decision premises of family influence, and analyse the impact of each on trust in leader. By portraying a picture of trust in leader in family businesses, we endeavour to make contributions to the family business research at the intersection of family influence and trust.

\section{Case Study of EM}

\section{Family Influence and Particularistic Trust}

The business family of EM was deeply devoted to the start-up, due to the family's influence over the continuity premise, and provided key resources at its initial stage, in various forms. For example, the founding of EM was fully financed from personal savings of the founder, who resigned from his position in the local government for his own business. The founder's wife also quitted her job in an SOE (state-owned enterprise) to be in full-time charge of the start-up's external networking. EM's employees were all local residents and many were distant relatives of the founder. In this context, particularistic trust was arguably made out of the competence of the leader in organising resources necessary for the business, as well as the common identity, shared by the leader and employees.

The business family of EM had a strong influence on the business via the command premise, especially at the founding stage. For instance, the founder once fired a distant relative who repeatedly made mistakes. This incident left the founder with an image of power and might, which was welcomed by the employees. As the office administrator recalled, "He was sharp and firm with the bottom lines... we thought he was a fair and trustworthy boss."

Family influence via the community premise was also explicit at EM. From the start-up, EM kept a core management team that included only the owning family members. This ongoing practice helped the business to achieve a high level of consistency in decision-making, hence the leader's reliability was established. This was reflected by the office administrator, who revealed, "We are all 
part of the village, and they [the business family] know us well... we [employees] don't have to worry about decisions, since they certainly know what they are doing."

With regard to the connection premise, EM initially relied on the founder's personal networks in the local government. For example, EM was able to access first-hand information about the government's regulation updates with more clarity through the founder's former classmates who worked in the local government. Personal connections also facilitated the business to participate in major regional trade fairs and hence secure market access. Employees as a result were assured that the business was secure and stable because of the founder's competence.

\section{Family Influence and System Trust}

After the inception of EM, it took nearly ten years before its business gradually moved into the mature stage. In 2008, the founder passed on the baton to the second generation, though the company still engaged with the same range of products as in the founding generation. EM's succession approach was gradual and smooth, in which the founder mentored and assisted his son for nearly ten years before succession. At the mature stage, even after succession, the business family of EM still placed explicit emphasis on family ownership and its continuity. The business model did not change, and key positions were either taken by family members or long-serving employees from the founding generation. Our interviews and observations suggested that personal relationship-based particularistic trust still prevailed.

Family influence via the command premise was strong at EM, even after succession. The retired founder remained "advisor" and was frequently consulted for strategic decision-making. Midlevel managers were mostly non-family members, who had worked in the business since its inception. The business family tended to rely on these non-family founding employees' expertise and loyalty after the founder's "retirement". Nevertheless, frontline employees did not have opportunities to participate in decision-making, nor any clue of the decision-making procedures. 
At the mature stage, EM still sought community via considerable family and kinship ties. As the owner-manager claimed, "Most employees are from this village and we share the same surname... we're naturally one big family." Informal strong ties were ubiquitous, within and around the business. EM's community remained clannish, insular, and inward-looking, largely based on interpersonal interactions.

Notwithstanding the business maturation, EM decided to maintain its existing connections with external stakeholders including suppliers, clients, and governments. These networks, though important as a resource base bolstering competitive advantages, were few in number and narrow in range. Personal ties prevailed in the connection processes, with a lack of transparency. As the owner-manager stated, "Although retired, my father is still around; this is actually good for the business, as he maintains the key relationships... I certainly know them too, but my father has worked with them for so many years that it is much easier for him to liaise with them."

\section{Case Study of ED}

\section{Family Influence and Particularistic Trust}

Similar to EM, the start of ED was fully financed by the founder, who left his SOE position. Family support was explicit, underpinning the continuity premise, which was recognised by the founding employees who were mostly the founder's former colleagues at the SOE. These employees, through their shared past experience of working with the founder at the SOE, already had adequate understanding of the founder's competence and reliability. Given the family influence on continuity, they had stronger trust in the founder's determination and capability of starting and continuing a promising business. The owner-manager commented, "All founding employees were friends of my father and the family... they could have chosen to stay [in the SOE], but they chose to risk following my father, because they trusted him through many years' work." 
Also similar to EM, family influence via the command premise was strong at ED, particularly at its early stage. For example, soon after the firm's inception, the founder showed his competence by insisting on acquiring a local restaurant and turning it into a staff canteen. Though the management team did not like the idea because of the concern about increased operational costs, the acquisition provided extra benefit to employees and resulted in their extended particularistic trust in the founder.

With regard to family influence via the community premise, ED's tradition emphasised that "the company is virtually a big family", hence the founder looked after employees' career and personal lives, especially those on key positions. But in terms of decision-making, the founder highlighted the importance of involving only those who were closely related to him; as he explained, "it was impossible, and unnecessary, to include many in decision-making, which would only prolong the process and potentially create conflicts."

Throughout its start and growth, the founder's connection activities endowed the business with membership in the local chamber of commerce, access to regional and national trade fairs, and business visits organised and funded by the local government. Most of these connections were built through the founder's past experiences in the SOE and personal networks in the local government. Arguably, the employees' observation of the founder's ability to maintain and capitalise on these experiences and networks contributed to their confidence in the founder's competence and reliability, hence particularistic trust in him as a business leader.

\section{Family Influence and System Trust}

Compared to EM, ED took longer to move into the mature stage. In effect, the business only ripened with established customer and supplier networks after 2010, which was roughly 16 years after the startup when the founder's daughter took over the reign from her father. It was then that the business family's influence via the continuity premise became less explicit. After the transfer of ownership, the business changed significantly, mainly because "the previous business was declining too badly to turn 
back". The owner-manager virtually started a new business with different products and processes from her father's. Her view on continuity focused more on the business side than the family side, "I'd rather not label it a family business, although all finances are from my family...". Comparing with the founding generation, the business now had a clearly-defined transparent structure and well-specified role responsibilities. Employees perceived the owner-manager and her team primarily as fair and capable professionals, besides representatives of the business family.

At the mature stage, family influence via the command premise changed. In its workforce, the owner-manager was the only one from the business family, and all other positions - management and non-management - were taken through a "structured merit-based recruitment procedure". Also, employees were organised into workgroups, which were working units where employees had opportunities to discuss and make suggestions on the company's development. In this way, decisionmaking became a "business process" instead of a "personal activity".

As far as the community premise is concerned, ED endeavoured to shape and benefit from a caring organisational culture, in which, as the owner-manager described, "everyone is connected with his or her colleagues and the business, not only in the manner of employment but also emotionally... so that they take coming to work as returning home". At the mature stage, ED took broader community activities. Different from their counterparts at EM, ED's employees were not personally related, and there was hardly any family or kinship clannishness that the business could rely on in its pursuit for community. ED thus institutionalised an organisational culture through transparent and fair procedures and policies, and this was well embraced by the employees.

ED broadened its external connections at the mature stage, mainly oriented by market practices instead of personal closeness. Benefiting from the initial connections, the company extended its external connections. As the owner-manager pointed out, there was a danger in tying up with a few suppliers, thus she would rather "explore" the width of the market. A similar approach was taken to 
managing its customer relationships. These transparent and systematic practices were appreciated by the employees.

\section{Case Study of WD}

\section{Family Influence and Particularistic Trust}

During business creation the family offered tangible resources and spiritual support, because of the family influence via the continuity premise. The founding finance was predominantly granted by the founder's mother. The father introduced potential clients to WD, given his role as general manager in a car-repairing SOE and the resultant well-knitted social connections. The strong family influence also drove the employees to build up collaborative or even pseudo-family relationships. Unlike EM but similar to ED, employees at WD were mainly recruited externally. Most of them had little industrial knowhow, the founder therefore mentored key subordinates and offered consultation whenever possible. Strong personal relationships stemmed from the interaction, and they were further enhanced by the founder's competence and caring nature, which fostered the employees' particularistic trust.

The founder of WD had a strong inclination of command and control. While regarded as a benevolent and talented leader, the founder sometimes showed the tough side of her personality. When negotiating with the global suppliers for a regional agency agreement, for instance, she commanded exclusive dealership at all times. The branch manager commented, "Our founder is shrewd and tough in strategies. The exclusive dealership bestows the firm a substantial space... we are confident in the firm and our leader".

Family influence via the community premise at WD was reflected in the development of personal ties at the initial stage. For example, the founder handpicked a marketing professional, and sent her to specialised external training, which was expensive for small businesses like WD. In this context, training was used as a privileged means to show the founder's care. Those who received training reciprocated with the allegiance to the business with the leader at the helm. 
Family influence via the connection premise initially was reflected in the founder's personal networks in the local government. Similar to the other cases, the connections were critical because they brought in resources essential for the construction of competitive advantages. WD received assistance from local communities, as a consequence of the founder's connections, including free management consultancy, access to associations, trade fairs, and professional institutes, as well as financial support. The promising start inspired employees' trust in their leader.

\section{Family Influence and System Trust}

In 2005, seven years after its initiation, WD became mature with its established organisational structure, experienced employees, and crafted industrial networks. At this phase, despite the fact that the business was initiated by the family, WD was not hostaged by the continuity of family ownership. The founder commenced to encourage equity investment from non-family members, thus the ownership structure of WD was unique. In 2018, three ownership regimes coexisted: a) 100\% family ownership in two franchising shops; b) majority ownership in the headquarters and three franchising shops; and c) no family ownership in 13 franchising shops which were owned by the shop managers. In fact, policies on new shop launch, marketing, performance appraisal, and staff recruitment had been developed and enacted. Staff members liked these policies and rules because of their lucidity and fairness.

With regard to family influence via the command premise, WD had its own feature. While family members were welcomed to join the business and take key positions, non-family members were also warmly embraced. A total of 13 shops were owned by long-serving loyal employees. The shops were bonded to the head-quarters via contracts, which stipulated that they should source licensed products from the head-quarters. In general, the policies and procedures catalysed professionalism and system trust.

Moving into the mature stage, WD institutionalised its influence on the community premise via internal policies, intending to create a caring, value-creating and cohesive environment. The business 
invested in the community construction along two directions. Firstly, benefiting from initial external off-the-job training, WD operationalised internal on-the-job training regularly thereafter. All staff members were encouraged to participate and this was specified in the company's policies. Secondly, WD devoted itself to nurturing a caring organisational culture via organising business-based social gatherings. The founder claimed, "We work in a big family and should treat each other like brothers and sisters. All of us are connected, not necessarily through blood relationship, but through teamwork". As such, the business had a chance to build a robust business-employee bond through stipulating transparent policies and procedures. In return it reaped the benefit of system trust.

Highly family-influenced businesses often build up enduring alliances with a small number of business partners. They are interested in the depth of connections, not the breadth. Yet, WD at the mature stage actively expanded its connections with business partners. It maintained a long list of suppliers, whose credibility and reliability were frequently reviewed. A similar procedure was followed for its customers. The reviewing and optimising procedure overcame the hurdle of managerial rigid mentality, and employees consequently were confident in their leaders.

\section{Cross-case Analysis}

Putting the three cases together, insights can be generated to understand trust in family business leaders. It is notable that trust in leader evolved over time in all cases. Table 3 provides a summary of the main findings on family influence and trust in leader from our cases.

\section{Insert Table 3 here}

\section{Initial Stage}

When founded, due to a constrained reach of resources and capabilities, the businesses commonly chose to rely on family resources and ongoing support. A clearly-defined business governance structure was not available, and decision-making was heavily dependent on the founders and their families. In 
our cases, family influence tended to be high on the four decision premises. This drove the family business leaders to demonstrate their competent, reliable, open, and caring nature, and they nurtured and subsequently reinforced the relationship-based particularistic trust.

Specifically, high family influence via the continuity premise led to recursive continuity communication in our cases, enabling the shared identity and vision among both family and non-family employees. The homogenous cognition motivated the leaders to use their competence and caring nature to keep these firms not only as family businesses, but also as business families (Lewicki and Bunker 1996). In addition, the homogenous cognition enabled the founders to be open to their subordinates. In all our cases, the founding workforce was notably connected to the leaders, through the kinship ties (EM), shared past experiences (ED), and individual mentorship (WD). The emotional bonds were strong, and were further strengthened by the founders' open approach, hence particularistic trust in the three case companies prevailed.

Family influence via the command premise motivates the owner-managers to rely on the internal employees, instead of externals, in their decision-making (Gómez-Mejía, Haynes, NunezNickel, Jacobson, and Moyano-Fuentes 2007). This is more of the case in EM and ED. Though externals might possess industrial expertise and knowledge, the leaders concerned whether their decision-making power might be hijacked, especially when their own authority in the business was not established. Therefore, the owner-managers of our cases formed particularistic groups and relied on their capabilities and personal approaches to hold the group tightly.

Strong family influence via communicatively constructed community premise contributes to a closer leader-follower relationship, which encourages leaders to show a competent, reliable, open, and caring nature, and employees to "behave as stewards" (Chirico and Bau 2014). In our cases, due to strong family influence on the community premise, family and non-family employees were able to maintain high-quality relationships (this is more explicit in ED and WD), characterised by respect and mutual obligations (Graen and Uhl-Bien 1995). Employees in such relationships trusted their leaders 
and committed to value-producing activities and organisational citizenship behaviour (Mayer and Gavin 2005).

Family influence via the connection premise impels networking. At the early stage, our case companies did not own rich or robust connections with external stakeholders. What they held were mostly internal information channels, primarily built upon the support from family members, and sporadic external channels, such as loose links with professional organisations (Hoffman et al. 2006). Under this circumstance, the owner-managers endeavoured, based on their competence, to acquire resources and access to tacit knowledge (Lechner, Dowling, and Welpe 2006). The promising start inspired employees' trust in their leaders.

\section{Mature Stage}

As businesses grew into the mature stage (about seven years for WD, 16 years for ED, and ten years for EM), they were in need of a wider span of resources and capabilities. Sole reliance on the business family for these resources and capabilities became difficult. Overall, the intensity of family influence decreased from the initial stage, but varied among cases. In particular, WD developed a relatively explicit management system, which incorporated the business family's core values but placed considerable emphasis on the formal business system. As a consequence, the foci of communication within the business shifted away from the attributes of the leader to the nature of the system. ED experienced a similar change at the mature stage. After the generational succession, family influence remained on all decision premises, but less intensively compared with the initial stage, partly because of the development of policies and procedures that translated family values into business values. EM stayed behind the other two companies in its evolution of trust in leader. It continued to have strong family influence in its second generation. Almost all practices initiated by its founding generation continued, and employees were personally connected in general. Particularistic trust that was 
communicatively constructed based on the leader's nature still prevailed, with vague indications of system trust.

When continuity is emphasised, executive leaders often encourage family members to join the firm, or take senior positions irrespective of their competency, as we can see from EM. Though what occurred in EM seemed to have addressed the company's continuity concern, this staffing approach had a negative impact on the employees' system trust. ED and WD took a different approach. Instead of bringing in family members to satisfy the continuity concern, they committed to the system development. The communication therefore recursively occurred on the nature of the system. Institution-based trust emerged as a result of this communication, albeit the extent of trust differing in the two companies.

Family influence via the command premise motivates owner-managers to use their own people in decision-making (Gómez-Mejía et al. 2007), rather than building up transparent and fair procedures and policies. Such impetus may cause confrontations, as non-family members perceive it as resistance against their upward mobility (Morris, Williams, Allen, and Avila 1997). In EM, high family influence hindered the development of system trust, where employees were mostly indifferent about the company's strategic vision. In ED and WD, with the development and implementation of transparent and fair policies and procedures, employee involvement increased, enabling a motivated and unified workforce, as well as system trust.

At the mature stage, strong family influence via the community premise can trigger the employees' suspicion about the transparency and fairness at workplace. This will demotivate their involvement in, and contribution to, the business (Gould-Williams 2003). Moreover, leaders in highly family-influenced businesses often enjoy their personal prestige via the community (Berrone, Cruz, Gómez-Mejía, and Larraza 2010). They may choose to defer the development of institutional policies and procedures to avoid loss of their status (Konig et al. 2013). The strong family influence on community is evident in the case of EM, where, for example, an implicit but important principle of 
recruitment was family relatedness. In contrast, ED and WD had introduced more market-oriented recruitment processes. This resulted in more diverse workforces, and more communication in relation to the business system.

Last but not least, strong family influence via the connection premise prompts businesses to network for the depth, rather than breadth, of external resources (Classen, Van Gils, Bammens, and Carree 2012). Miller and Le Breton-Miller (2005) recognised that highly family-influenced businesses often have long-standing relationships with a small number of external stakeholders. But continued reliance on a narrow range of external stakeholders does not lead to transparency in connection, and can further result in managerial "tunnel vision" (Finkelstein and Hambrick 1990), or a rigid mentality (Konig et al. 2013). The leader's narrow and rigid mindset often undermines employees' confidence in the business, as evidenced in the worry of EM's R\&D team leader about the company's implicit and sole reliance on the local government funding for its product development projects. ED and WD, on the other hand, were able to access external resources via a more transparent approach and from a wider range.

\section{Discussion and Conclusion}

Trust is a critical source of competitive advantage for family businesses (Steier 2001). However, current knowledge of trust in the literature is primarily related to non-family businesses, whereas trust in family businesses to an extent is overlooked, albeit these businesses being the most common economic organisations world-wide. Our study attempts to examine trust in family businesses and we endeavour to make contributions to the family business literature.

Specifically, our study builds on the work of Sundaramurthy (2008), Tan et al. (2009), Shi et al. (2015), as well as Miller and Le Breton-Miller (2005) and Frank et al. (2017), to seek insights into the emergence and evolution of trust in family business leaders, and more importantly the impact of family influence on trust in leader. To do so, we adopt a dynamic perspective. We argue that trust in leader 
varies across the business life cycle and tends to demonstrate distinct features at different phases. We investigate the impact of family influence on trust in leader from the $\mathrm{nST}$, rather than the traditional resource-based, social capital, or network perspective. We contend that business families can influence business decisions via decision premises, and that different decision premises exist for particularistic and system trust. This way, we reduce the complexity in understanding family influence, trust, as well as their nexus, as the nST offers a clear theoretical lens to examine business issues.

Our first finding shows that different types of trust exists in family businesses, and that trust in leader evolves, though the pace of evolution varies. In the literature, when trust is examined, researchers usually take on board a static perspective. This has been evidenced in an array of studies in the literature on trust in leader, its antecedents as well as the behaviour and performance outcomes (Dirks and Ferrin 2002; Burke et al. 2007). Nevertheless, given the dynamically changing environment, using a dynamic perspective to scrutinise trust in businesses is arguably more appropriate. The outcome of our study confirms this viewpoint, hence a non-trivial finding. Moreover, in the limited family business trust literature, Morris, Allen, Kurakto and Brannon (2010) and Pearson and Marler (2010) look into family business leaders' imprints on trust (cf., Eddleston et al. 2010). Morris et al. (2010) found that the family can be a source of support, facilitating the founder in creating a business venture. This support may lead to the founder's positive emotions, and he/she will then build up trusting relationships with subordinates. Pearson and Marler (2010) found that family business leaders who are able to create good relationships with family and non-family employees can nurture stewardship in the business. Our study resonates with Pearson and Marler (2010) and Morris et al. (2010) and goes further, since we take into account the influence of the entire business families including the ownermanagers. We observe that one of the key functions the business family has is to establish decision premises in the business through communication and exert its influence via the premises. The presence of these decision premises ensures the alignment of business decisions with a set of family values and practices, therefore, even when the family is not present, family influence continues (Suess-Reyes 
2017). More importantly, our results reveal that the heightened family influence via family-induced decision premises exerts positive impact on particularistic trust at the business initial stage but negative effect on system trust at the mature stage. This finding is original, while the nexus between family influence and trust has implications on business practical operations.

\section{Contributions}

The study adopts the nST, which is a theoretical framework that has recently been applied to family business research (e.g., Von Schlippe and Frank 2013; Frank et al. 2017; Hasenzagl et al. 2018). In particular, we concentrate on decision premises (Simon 1957) for family influence, particularistic trust, and system trust. By doing so, we enable the examination of a potentially complicated research problem, that is, the impact of family influence on trust in leader. Our finding represents a contribution, which suggests that a nexus exists between family influence and trust in leader. Meanwhile, our research extends the application of the $\mathrm{nST}$ in the family business domain and leaves a noteworthy footprint in the territory. Secondly, trust may vary according to time and business context (Steier 2001). Our study focuses on trust evolution along the time horizon. Our findings endorse Sundaramurthy's (2008) viewpoint with empirical evidence, and show the necessity of using the dynamic perspective in the trust research. Finally, trust and its evolution in family businesses are shaped by the idiosyncratic institutional environment, as well as dictated by historical, cultural, and even geographical traditions. This study is executed in China, a transitional economy with family businesses emerging after 1979 and flourishing since the 1990s. Due to the underdeveloped state of formal institutions, family businesses, compared with their state-owned and collective-owned counterparts, receive a low level of legal and institutional protection (Tan 2002). Trust hence plays an important role in business operations, since maintaining trust at a high level, irrespective of relationship-based particularistic trust or institution-based system trust, may offset the negative bearing caused by the underdeveloped formal institutions. The study uniquely juxtaposes insights from multiple angles including Chinese socio- 
economic-cultural context, trust in leader, and family influence. Research findings advance our understanding on how family businesses in China are able to survive, evolve, and thrive.

\section{Managerial Implications}

Frank and Landstrom (2015) pointed out that the institutionalisation of entrepreneurship research often favours rigour over relevance of research, resulting in a rigour-relevance gap. They suggested that researchers focus on the creation of applicative knowledge rather than rigour of research exclusively. As such, we attempt the knowledge arising from the study that can be practically applicable. Herein we highlight three inter-related implications. Firstly, the literature suggests that family businesses are a fertile ground for both trust and distrust. Trust can facilitate knowledge creation (Lin 2001), channel the employees' momentum towards the same direction, and ease business governance (Eddleston et al. 2010). Trust in essence is "a fundamental basis for cooperation" (Steier, 2001, p.354). When trust exists, an "escalating" operational process can be expected. Nevertheless, trust is fragile and can easily be destroyed (Sundaramurphy, 2008). Distrust may cause dysfunctional relationships, business complexity, and paralysis of actions (Pearson, Carr, and Shaw 2008). It is therefore legitimate to suggest that family business leaders consider nurturing a trust and stewardship culture in their firms. Particularly, a trust fostering and developing charter can be taken into account, which covers for instance the importance of family business engaging in the trust construction, the role of family and non-family members in this process, the mechanisms and procedures to address trust-related conflicts, and the reviewing process for continued trust development.

Secondly, the study finds relationship-based particularistic trust is particularly valuable initially. As businesses mature, a barrier against business development is that executive leaders continuously rely on relationship-based trust and ignore the necessity of developing institution-based system trust. The EM's case is in this vein. Thus we suggest that executive leaders take into account the evolutionary 
nature of trust. In fact, not only does trust show an evolutionary nature, the decision premises for trust evolve as well. The study reveals the decision premises of particularistic and system trust differ, with the former signified by the leader's personal nature and the latter by the attributes of the business system. March and Simon (1958) in their landmark book "Organizations" indicated that organisations, whenever possible, seek to reduce uncertainty. They further argued that decision premises can serve as a mechanism of uncertainty absorption, since the premises set up expectations as to what information is required for decision, channel the information flow, and alert to the organisation when a risky signal is received (Perrow, 1986). Given the importance of decision premises, particularly their relationship with trust in this study's context, entrepreneurs should pay attention to their function and review their role regularly.

Thirdly, the study shows that a high level of family influence can be translated into a high level of particularistic trust, but a diminished level of system trust. This implies that the holding families should be cautious about their influence, if the firm's long-term prosperity is concerned, and be vigilant whether their influence inspires confidence, engagement, and loyalty from their subordinates. Specifically, at the initial stage family firms should heighten their influence via the decision premises. At the mature stage, firms should strategically tone down their family influence and facilitate the erection of organisational policies and procedures on governance and business development.

\section{Limitations of the Study}

This study is not short of limitations, one of which is related to the research environment. In China, businesses overall are not familiar with empirical research or data collection approaches such as interviews and questionnaire surveys. This was manifested that some interviewees did not feel comfortable in the interviews. Information garnered therefore may not portray the picture to a robust extent. Secondly, family business as a business entity is relatively new in China. Due to the ideological concern and the fact that China had been in a planned economy for long, family businesses often 
struggle with the family icon, especially in communication. Though the three companies involved accepted our research invitation, the extent of revelation of family related issues was uncertain. Thirdly, Ralston, Yu, Wang, Terpstra, Gustafson, and Wei (1996) recognised wide-ranging variations among managers from different regions of China. Whilst regional culture may have an impact on managers, the level of regional economy also shapes business operations. The three participating companies in the current study are from two regions, Jiangsu and Xinjiang respectively, which only capture limited indigenous features of China and consequently limit the generalisability of the study. Finally, the study is executed in China, a transitional economy with rich social, historical, and geographical contexts of trust. The research setting, while offering a convincing venue for examining family business and trust, suggests the study has limited generalisability, since the evolution and the dynamic nature of trust in leader in family businesses are deeply rooted in the specific institutional environment.

\section{Directions for Future Research}

Following this empirical work, several directions for future research can be envisaged. Firstly, as the topic has only been qualitatively examined, it needs validation through quantitative studies. To empirically test the relationships reported by the current study, researchers need to develop reliable and valid measurements to measure constructs reflected in this study, including family influence over the continuity, command, community, and connection premises, particularistic trust, and system trust. These measurements form the foundation for the quantitative study. Future studies could also delve into the intervening effects of individual, organisational, and industrial variables, while testing the nexus between family influence and trust. The literature shows that the repertoire of skills of the entrepreneur (Lee and Venkataraman 2006), the age and history of the business, and the characteristics of the industry may influence trust in leader (Tan et al. 2009). Via incorporating individual, organisational, and industrial variables, more comprehensive understanding of antecedents to 
particularistic and system trust can be achieved. Finally, if we move one step further to stretch the research boundary to incorporate non-family businesses, the impact of variables on particularistic and system trust at different levels can be revisited. Such empirical comparison may enable researchers to develop more incisive understanding of trust in leader.

\section{References}

Allen, M.R., George, B.A., and Davis, J.H. (2018). "A model for the role of trust in firm level performance: The case of family businesses", Journal of Business Research, 84(1), 34-45.

Argyris, C. (1962). Interpersonal Competence and Organisational Effectiveness. Homewood, IL: Dorsey Press.

Bass, B.M. (1990). Bass and Stogdill's Handbook of Leadership: Theory, Research, and Managerial Application. New York, NY: Free Press.

Berrone, P., Cruz, C., Gómez-Mejía, L.R., and Larraza, M. (2010). "Socioemotional wealth and corporate responses to institutional pressures: Do family-controlled firms pollute less?" Administrative Science Quarterly, 55(1), 82-113.

Burke, C.S., Sims, D.E., Lazzara, E.H., and Salas, E. (2007). "Trust in leadership: A multi-level review and integration", The Leadership Quarterly, 18(6), 606-632.

Carnes, C.M. and Ireland, R.D. (2013). "Familiness and innovation: Resource bundling as the missing link", Entrepreneurship Theory and Practice, 37(6), 1399-1419.

Chirico, F. and Bau, M. (2014). "Is the family an 'asset' or 'liability' for firm performance? The moderating role of environmental dynamism”, Journal of Small Business Management, 52(2), 210-225.

Chrisman, J.J., Chua, J.H., and Litz, R.A. (2004). "Comparing the agency costs of family and nonfamily firms: Conceptual issues and exploratory evidence”, Entrepreneurship Theory and Practice, 28(4), 335-354.

Chrisman, J.J., Chua, J.H., and Steier, L. (2005). "Sources and consequences of distinctive familiness: An introduction", Entrepreneurship Theory and Practice, 29(3), 237-247.

Chrisman, J.J., Chua, J.H., De Massis, A., Frattini, F., and Wright, M. (2015). "The ability and willingness paradox in family firm innovation", Journal of Product Innovation Management, 32(3), 310-318.

Classen, N., Van Gils, A., Bammens, Y., and Carree, M. (2012). "Accessing resources from innovation partners: The search breadth of family SMEs", Journal of Small Business Management, 50(2), 191-215.

Creswell, J.W. (1994). Research Design: Qualitative and Quantitative Approaches. Thousand Oaks, CA: Sage.

Croonen, E. (2010). "Trust and fairness during strategic change processes in franchise systems", Journal of Business Ethics, 95(2), 191-209.

Danermark, B., Ekstrom, M., Jakobsen, L., and Karlsson, J. (2002). Explaining Society: Critical Realism in the Social Sciences. London: Routledge.

Dalpiaz, E., Tracey, P., and Phillips, N. (2014). "Succession narratives in family business: The case of Alessi”, Entrepreneurship Theory and Practice, 38(6), 1375-1394.

Davis, J.H., Allen, M.R., and Hayes, H.D. (2010). "Is blood thicker than water? A study of stewardship perceptions in family business", Entrepreneurship Theory and Practice, 34(6), 1093-1116. 
Davis, J.H., Schoorman, F.D., and Donaldson, L. (1997). "Toward a stewardship theory of management", Academy of Management Review, 22(1), 20-47.

De Massis, A., Frattini, F., Pizzurno, E., and Cassia, L. (2015). "Product innovation in family versus nonfamily firms: An exploratory analysis", Journal of Small Business Management, 53(1), 1-36.

De Massis, A., Sharma, P., Chua, J., and Chrisman, J. (2012). Family Business Studies: An Annotated Bibliography. Northampton, UK: Edward Elgar.

Dirks, K.T. and Ferrin, D.L. (2002). "Trust in leadership: Meta-analytic findings and implications for research and practice", Journal of Applied Psychology, 87(4), 611-628.

Eddleston, K.A., Chrisman, J.J., Steier, L.P., and Chua, J.H. (2010). "Governance and trust in family firms: An introduction", Entrepreneurship Theory and Practice, 34(6), 1043-1056.

Eisenhardt, K.M. (1989). "Building theories from case study research", Academy of Management Review, 14(4), 532-550.

Eisenhardt, K.M. and Graebner, M.E. (2007). "Theory building from cases: Opportunities and challenges", Academy of Management Journal, 50(1), 25-32.

Eisenhardt, K.M. and Martin, J.A. (2000). "Dynamic capabilities: What are they?" Strategic Management Journal, 21(10), 1105-1121.

Finkelstein, S. and Hambrick, D.C. (1990). "Top-management-team tenure and organisational outcomes: The moderating role of managerial discretion”, Administrative Science Quarterly, 35(3), 484-503.

Frank, H. and Landstrom, H. (2015). "What makes entrepreneurship research interesting? Reflections on strategies to overcome the rigour-relevance gap", Entrepreneurship and Regional Development, 28(1-2), 51-75.

Frank, H., Kessler, A., Rusch, T., Suess-Reyes, J., and Weismeier-Sammer, D. (2017). "Capturing the familiness of family businesses: Development of the Family Influence Familiness Scale (FIFS)", Entrepreneurship Theory and Practice, 41(5), 709-742.

Gersick, K.E., Davis, J.A., Hampton, M.M., and Lansberg, I. (1997). Generation to Generation: Life Cycle of the Family Business. Boston, MA: Harvard Business School Press.

Gómez-Mejía, L.R., Haynes, K.T., Núñez-Nickel, M., Jacobson, K.J.L., and Moyano-Fuentes, J. (2007). "Socioemotional wealth and business risks in family-controlled firms: Evidence from Spanish olive oil mills", Administrative Science Quarterly, 52(1), 106-137.

González-Cruz, T.F. and Cruz-Ros, S. (2016). "When does family involvement produce superior performance in SME family business?” Journal of Business Research, 69(4), 1452-1457.

Gould-Williams, J. (2003). "The importance of HR practices and workplace trust in achieving superior performance: A study of public sector organisations", International Journal of Human Resource Management, 14(1), 28-54.

Graen, G.B. and Uhl-Bien, M. (1995). "Relationship-based approach to leadership: Development of leader-member exchange (LMX) theory of leadership over 25 years: Applying a multi-level multi-domain perspective", Leadership Quarterly, 6(2), 219-247.

Habbershon, T.G. and Williams, M.L. (1999). "A resource-based framework for assessing the strategic advantages of family firms", Family Business Review, 12(1), 1-25.

Habbershon, T.G., Williams, M.L., and McMillan, I.C. (2003). "A unified systems perspective of family firm performance", Journal of Business Venturing, 18(4), 451-465.

Harkness, J.A. (2003). "Questionnaire translation", in Cross-cultural Survey Methods. Eds. J.A. Harkness, F.J.R. van de Vijver, and P.P. Mohler. New York, NY: John Wiley \& Sons.

Hasenzagl, R., Hatak, I., and Frank H. (2018). "Problematising socioemotional wealth in family firms: A systems-theoretical reframing", Entrepreneurship and Regional Development, 30(1-2), 199223.

Heyden, L.V.D., Blondel, C., and Carlock, R.S. (2005). "Fair process: Striving for justice in family businesses", Family Business Review, 18(1), 1-21. 
Hoffman, J., Hoelscher, M., and Sorenson, R. (2006). "Achieving sustained competitive advantage: A family capital theory", Family Business Review, 19(2), 135-145.

Jiang, S., Gong L., Wang H., and Kimble, C. (2016). "Institution, strategy, and performance: A coevolution model in transitional China", Journal of Business Research, 69(9), 3352-3360.

Konig, A., Kammerlander, N., and Enders, A. (2013). "The family innovator's dilemma: How family influence affects the adoption of discontinuous technologies by incumbent firms", Academy of Management Review, 38(3), 418-441.

Kontinen, T. and Ojala, A. (2011). "International opportunity recognition among small and mediumsized family firms", Journal of Small Business Management, 49(3), 490-514.

Lansberg, I. (1999). Succeeding Generation. Boston, MA: Harvard Business School Press.

Lechner, C., Dowling, M., and Welpe, I. (2006). "Firm networks and firm development: The role of the relational mix", Journal of Business Venturing, 21(4), 514-540.

Lee, J.H. and Venkataraman, S. (2006). "Aspirations, market offerings, and the pursuit of entrepreneurial opportunities", Journal of Business Venturing, 21(1), 107-123.

Lewicki, R.J. and Bunker, B.B. (1996). "Developing and maintaining trust in work relationships", in Trust in Organisations: Frontiers of Theory and Research. Eds. R.M. Kramer and T.R. Tyler, 114-139.

Lin, N. (2001). Social Capital: A Theory of Social Structure and Action. Cambridge, MA: Cambridge University Press.

Luhmann, N. (1979). Trust and Power. New York, NY: Wiley.

Luhmann, N. (1995). Social System. Stanford, CA: Stanford University Press.

Luhmann, N. (2013). Introduction to Systems Theory. Cambridge, UK: Polity Press.

March, J.G. and Simon, H.A. (1958) Organizations. New York, NY: Wiley.

Marshal, C. and Rossman, G. (1999). Designing Qualitative Research (3 ${ }^{\text {rd }}$ ed.). London: Sage.

Mattheis C. (2012). "The system theory of Niklas Luhmann and the constitutionalisation of the world society", Goettingen Journal of International Law, 4(2), 625-647.

Mayer, R.C. and Gavin, M.B. (2005). "Trust in management and performance: Who minds the shop while the employees watch the boss?" Academy of Management Journal, 48(5), 874-888.

Merriam, S.B. (1988). Case Study Research in Education: A Qualitative Approach. San Francisco, CA: Jossey-Bass.

Miller, D. and Le Breton-Miller, I. (2005). "Management insights from great and struggling family businesses", Long Range Planning, 38(6), 517-530.

Miller, D., Le Breton-Miller, I., and Lester,R.H. (2010). "Family ownership and acquisition behaviour in publicly traded companies", Strategic Management Journal, 31(2), 201-223.

Mishra, A.K. and Spreitzer, G.M. (1998). "Explaining how survivors respond to downsizing: The roles of trust, empowerment, justice and work redesign', Academy of Management Review, 23(3), 567-588.

Morris, M.H., Allen, J.A., Kurakto, D.F., and Brannon, D. (2010). "Experiencing family business creation: Differences between founders, non-family managers, and founders of non-family firms", Entrepreneurship Theory and Practice, 34(6), 1057-1083.

Morris, M.H., Williams, R.O., Allen, J.A., and Avila, R.A. (1997). "Correlates of success in family business transitions", Journal of Business Venturing, 12(5), 385-401.

Pearson, A.W., Carr, J.C., and Shaw, J.C. (2008). "Toward a theory of familiness: A social capital perspective", Entrepreneurship Theory and Practice, 32(6), 949-969.

Pearson, A.W. and Marler, L.E. (2010). "A leadership perspective of reciprocal stewardship in family firms", Entrepreneurship Theory and Practice, 34(6), 1117-1123.

Perrow, C. (1986). Complex Organizations: A Critical Essay. New York, NY: Random House. 
Ralston, D.A., Yu, K.C., Wang, X., Terpstra, R.H., Gustafson, D.J., and Wei, H. (1996). "The cosmopolitan Chinese manager: findings of a study on managerial values across the six regions of China", Journal of International Management, 2(2), 79-109.

Reay, T. and Whetten, D.A. (2011). "What constitutes a theoretical contribution in family business?" Family Business Review, 24(2), 105-110.

Seidl, D. (2004). Luhmann's theory of autopoietic social systems, http://www.zfog.bwl.unimuenchen.de/files/mitarbeiter/paper2004_2.pdf.

Sharma, P., Chrisman, J.J., and Chua, J.H. (1996). A Review and Annotated Bibliography of Family Business Studies. Boston, MA: Kluwer Academic Publishers.

Shi, H.X., Shepherd, D.M., and Schmidts, T. (2015). "Social capital in entrepreneurial family businesses: The role of trust", International Journal of Entrepreneurial Behaviour and Research, 21(6), 814-841.

Simon, H.A. (1957). Models of Man, Social and Rational: Mathematical Essays on Rational Human Behaviour in a Social Setting. New York, NY: Wiley.

Sirmon, D.G. and Hitt, M.A. (2003). "Managing resources: Linking unique resources, management and wealth creation in family firms", Entrepreneurship Theory and Practice, 27(4), 339-358.

Steier, L. (2001). "Family firms, plural forms of governance, and the evolving role of trust", Family Business Review, 14(4), 353-368.

Suess-Reyes, J. (2017). "Understanding the transgenerational orientation of family businesses: The role of family governance and business family identity", Journal of Business Economics, 87(6), 749-777.

Sundaramurthy, C. (2008). "Sustaining trust within family businesses", Family Business Review, 21(1), 89-102.

Sydow, J. (1998). "Understanding the constitution of interorganisational trust", in Trust within and between Organisations. Eds. C. Lane and R. Bachmann. New York, NY: Oxford University Press, 31-63.

Tan, J. (2002). "Impact of ownership type on environment-strategy linkage and performance: Evidence from a transitional economy", Journal of Management Studies, 39(3), 333-354.

Tan, J., Yang, J., and Veliyath, R. (2009). "Particularistic and system trust among small and medium enterprises: A comparative study in China's transition economy", Journal of Business Venturing, 24(6), 544-557.

Tan, W.L. and Fock, S.T. (2001). "Coping with growth transitions: The case of Chinese family businesses in Singapore", Family Business Review, 14(2), 123-139.

Von Schlippe, A. and Frank, H. (2013). "The theory of social systems as a framework for understanding family businesses", Family Relations, 63(3), 384-398.

Wang Y. (2016a). "Environmental dynamism, trust, and dynamic capabilities of family businesses: Evidence from the UK", International Journal of Entrepreneurial Behaviour and Research, 22(5), 643-670.

Wang, Y. (2016b). "Investigating dynamic capabilities of family businesses in China: A social capital perspective”, Journal of Small Business and Enterprise Development, 23(4), 1057-1080.

Wang, Z., Huang, J., and Tan B. (2013). "Managing organisational identity in the e-commerce industry: An ambidexterity perspective", Information and Management, 50(8), 673-683.

Whitener, E.M. (1997). "The impact of human resource activities on employee trust", Human Resource Management Review, 7(4), 389-404.

Yamagishi, T., Cook, K.S., and Watabe, M. (1998). "Uncertainty, trust, and commitment formation in the United States and Japan", American Journal of Sociology, 104(1), 165-194.

Yin, R.K. (2009). Case Study Research: Design and Methods (4th ed.). Thousand Oaks, CA: Sage.

\section{Endnote}


${ }^{\mathrm{i}}$ In China, the definition of SMEs, according to the SME Promotion Law of China (2003), depends on the industry category and is based on the company's number of employees, registered assets, and annual revenue. A summary of SME definitions are shown below.

\begin{tabular}{lllll}
\hline $\begin{array}{c}\text { Size } \\
\text { category }\end{array}$ & \multicolumn{1}{c}{ Industry } & $\begin{array}{c}\text { Number of } \\
\text { employees }\end{array}$ & Registered assets & Annual revenue \\
\hline Small & Manufacturing & $<300$ & $<¥ 40 \mathrm{~m}$ & $<¥ 30 \mathrm{~m}$ \\
& Construction & $<600$ & $<¥ 40 \mathrm{~m}$ & $<¥ 30 \mathrm{~m}$ \\
& Wholesale & $<100$ & $<¥ 40 \mathrm{~m}$ & $<¥ 30 \mathrm{~m}$ \\
& Retail & $<100$ & $<¥ 40 \mathrm{~m}$ & $<¥ 10 \mathrm{~m}$ \\
Medium & Manufacturing & $300-2000$ & $¥ 40 \mathrm{~m}-400 \mathrm{~m}$ & $¥ 30 \mathrm{~m}-300 \mathrm{~m}$ \\
& Construction & $600-3000$ & $¥ 40 \mathrm{~m}-400 \mathrm{~m}$ & $¥ 30 \mathrm{~m}-300 \mathrm{~m}$ \\
& Wholesale & $100-200$ & $¥ 40 \mathrm{~m}-400 \mathrm{~m}$ & $¥ 30 \mathrm{~m}-300 \mathrm{~m}$ \\
& Retail & $100-500$ & $¥ 40 \mathrm{~m}-400 \mathrm{~m}$ & $¥ 10 \mathrm{~m}-150 \mathrm{~m}$ \\
\hline
\end{tabular}

Source: SME Promotion Law of China (2003) 
Table 1 Case Company Profile

\begin{tabular}{lrlccccl}
\hline Case Region & From & Main activities & $\begin{array}{c}\text { Registered } \\
\text { assets }\end{array}$ & $\begin{array}{c}\text { Annual } \\
\text { sales }\end{array}$ & $\begin{array}{c}\text { No. of } \\
\text { employees }\end{array}$ & Generation & Owned by \\
\hline EM Jiangsu & 1990 & $\begin{array}{l}\text { Vehicle parts } \\
\text { manufacturing }\end{array}$ & $¥ 10 \mathrm{~m}$ & $¥ 30 \mathrm{~m}$ & 70 & Second & Founder’s son \\
ED Jiangsu & 1994 & $\begin{array}{l}\text { Vehicle sales and } \\
\text { service }\end{array}$ & $¥ 20 \mathrm{~m}$ & $¥ 120 \mathrm{~m}$ & 120 & Second & $\begin{array}{l}\text { Founder’s } \\
\text { daughter }\end{array}$ \\
WDXinjiang & 1998 & $\begin{array}{l}\text { Vehicle parts } \\
\text { sales and service }\end{array}$ & $¥ 5 \mathrm{~m}$ & $¥ 40 \mathrm{~m}$ & 55 & First & $\begin{array}{l}\text { Founder and } \\
\text { family and non- } \\
\text { family staff } \\
\text { members }\end{array}$ \\
\hline
\end{tabular}

Table 2 Profile of Interviewees

\begin{tabular}{llllll}
\hline Case & Interviewee 1 & Interviewee 2 & Interviewee 3 & Interviewee 4 & Interviewee 5 \\
\hline EM & $\begin{array}{l}\text { Owner- } \\
\text { manager }\end{array}$ & $\begin{array}{l}\text { Deputy manager } \\
\text { (owner's brother) }\end{array}$ & $\begin{array}{l}\text { R\&D team } \\
\text { leader }\end{array}$ & $\begin{array}{l}\text { Machine } \\
\text { operator }\end{array}$ & $\begin{array}{l}\text { Office } \\
\text { administrator }\end{array}$ \\
ED & $\begin{array}{l}\text { Owner- } \\
\text { manager }\end{array}$ & Line manager & $\begin{array}{l}\text { Sales team } \\
\text { leader }\end{array}$ & $\begin{array}{l}\text { Sales } \\
\text { representative }\end{array}$ & Founder \\
WD & Founder & $\begin{array}{l}\text { Director of a head- } \\
\text { quarter (founder's } \\
\text { sister) }\end{array}$ & $\begin{array}{l}\text { Chief } \\
\text { accountant }\end{array}$ & Shop manager & ---- \\
\hline
\end{tabular}

Table 3 Family Influence and Trust in Leader

\begin{tabular}{|c|c|c|}
\hline & Particularistic Trust (Initial Stage) & System Trust (Mature Stage) \\
\hline $\begin{array}{l}\text { EM - Continuity } \\
\text { Highly } \\
\text { family- } \\
\text { influenced at } \\
\text { both initial } \\
\text { and mature } \\
\text { stages }\end{array}$ & $\begin{array}{l}\text { - Strong family influence via the } \\
\text { continuity premise - the start-up was fully } \\
\text { financed by the founder, who was a well- } \\
\text { paid public servant in the local government } \\
\text { previously. } \\
\text { - The founder's wife quitted her job } \\
\text { in an SOE, and devoted full-time to the } \\
\text { start-up's external networking and client } \\
\text { relationship management. } \\
\text { - All employees were local } \\
\text { residents; many were distant relatives of the } \\
\text { founder. } \\
\text { - "It was commonly acknowledged } \\
\text { that the business's survival and growth was } \\
\text { in everyone's personal interest... and as a } \\
\text { big family [clan], everyone did justice to the } \\
\text { business [continuity]" - the current owner- } \\
\text { manager. } \\
\text { - High level of particularistic trust - } \\
\text { particularistic trust in leader stemmed from } \\
\text { the competence of the leader in organising } \\
\text { resources and the close relationships } \\
\text { between the founder and employees. }\end{array}$ & $\begin{array}{l}\text { - Strong family influence via the } \\
\text { continuity premise - the founder mentored and } \\
\text { assisted his son for nearly ten years before } \\
\text { succession. After succession, the business } \\
\text { model did not really change, and key positions } \\
\text { were either taken by the owner's family } \\
\text { (brother as deputy manager, wife as book- } \\
\text { keeper) or founding employees, who } \\
\text { maintained personal ties with the owning } \\
\text { family, and particularly the retired founder. } \\
\text { - Low level of system trust - } \\
\text { development of policies and procedures was } \\
\text { started by the second generation. These } \\
\text { policies and procedures were still pre-mature. } \\
\text { "Personally, I am his [owner-manager's] } \\
\text { distant relative, but this was not how I came to } \\
\text { work here. After all, business is business... I } \\
\text { don't think having too much family } \\
\text { clannishness is good for the business" - the } \\
\text { machine operator. }\end{array}$ \\
\hline
\end{tabular}


Command

- Strong family influence via the command premise - the founder had low tolerance of employees' incapability. For instance, he fired a distant relative who repeatedly made careless and serious mistakes.

- High level of particularistic trust the incident left the founder with an image of power and might, which was welcomed by the employees. As the office administrator recalled, "Most of the time, he (the founder) tended to be flexible and easygoing, but he was sharp and firm with the bottom lines ... he fired his cousin and made the case known to everyone... we thought he was a trustable boss."

Community

- Strong family influence via the community premise - EM kept a core management team that included only the owning family members, delivering a high level of consistency in decision making and implementation of the business.

- High level of particularistic trust employees perceived the core decisionmaking team as providing consistency in business strategies, hence the leader's reliability was established. The office administrator reflected, "We are all part of the village, and they [the owning family] know us well... we [employees] don't have to worry about decisions, since they certainly know what they are doing."

Connection - Strong family influence via the connection premise - initial connections were based on the founder's personal networks in the local government.

- These connections helped EM to participate in major regional trade fairs, which facilitated its market access and customer relationships.

- High level of particularistic trust Given the key role that these connections played in the firm's performance, they were highly regarded not only by the management, but also the employees, who reckoned the business as secure and stable because of the founder's competence.
- Strong family influence via the command premise - the strong command nature continued after succession.

- All key positions were taken by the owner's family members. The founder was still frequently consulted for strategic decision-making. Mid-level managers were mostly long-serving employees. After the "retirement" of the founder, the owning family tended to rely on these non-family founding employees to manage and grow the business.

- Low level of system trust -frontline employees did not really take part in the business's decision-making. No transparent procedure was available. "After all, it is their family's business...", the machine operator reflected.

- Strong family influence via the community premise - EM sought community with considerable family or kinship ties.

- "Most employees are from this village and we bear the same surname... we're naturally one big family", the incumbent owner-manager claimed. His brother/deputy manager added, "Many of them [employees] are actually my distant relatives, some are my seniors..."

- Low level of system trust - No clear sign that system trust was established.

- Strong family influence via the connection premise - long lasting connections were critical for EM because these stakeholders provided resources which helped EM to develop strategic capabilities and competitive advantages.

- Personal ties and networks prevailed. Many connections were still based on the founder's former colleagues.

- $\quad$ The R\&D team leader reflected, "My team relies on the government grants... our ongoing receipt of them, as we all know, is very much dependant on the tie between his (the owner-manager's) father and the local government."

- Low level of system trust - No clear sign that system trust was built up.

- Mild family influence via the continuity premise - after the succession, the second-generation owner-manager virtually started a new business with different products
Highly

family-
Continuity

continuity premise - start-up fully financed by the founder, who was a senior manager in a local SOE previously. 


\section{influenced at \\ start-up; less \\ family- \\ influenced at \\ mature stage}

- The founder's brother worked in the business initially to oversee the production and then in charge of marketing.

- Founding employees were mostly the founder's former colleagues in the SOE.

- High level of particularistic trust "Most of them [founding employees] had spent numerous years with me in the SOE, and they chose to continue with me when I decided to start my own business... they were important assets to the business, especially at the beginning", the founder recalled. The current owner-manager further added, "The founding employees were friends of my father and the family... they could have chosen to stay [in the SOE] ....”.

Command

- Strong family influence via the command premise - the founder had exclusive power in decision making, which can be reflected in an early incident that he insisted acquiring a local restaurant and turned it into a staff canteen.

- High level of particularistic trust the acquisition of the restaurant resulted in extended particularistic trust in the leader because of his competence. As the founder reflected, "My management team didn't like my idea (about the staff canteen) ... because it would incur extra costs, and it truly did, but I thought it was good for the employees; they are the business, not just me or my own family... they (the employees) liked me better, I believe."

Community - Strong family influence via the community premise - the founder took the responsibility to look after employees' career and personal lives. This was enacted through organisational events and social gatherings.

- The founder highlighted the importance of involving only those who were closely related to him.

- High level of particularistic trust organisational events and social gathering motivated a sense of belonging of employees. Particularistic trust in the leader was nurtured due to his care of employees.

Connection

- Strong family influence via the connection premise - the founder had good connections with the local government or agencies.

- These connection activities endowed the business with membership in and processes. No other members from the family were formally employed.

- The incumbent owner-manager's view on business continuity focused more on the business side than the family side, "I'd rather not label it a family business... it matters more if the business keeps growing and prospering."

- $\quad$ High level of system trust - ED now had a clearly-defined transparent structure and position responsibilities. "[ED is] the one that is least like a family business, [because] the firm is so structured that everyone understands his or her responsibilities associated with the position... and you don't have the family boss instructing you at all times" - the line manager stated.

- Weak family influence via the command premise - after succession, the owner-manager was the only one from the owning family, and all other management positions were taken by personnel recruited from the job market, through a "structured merit-based recruitment procedure". The founder was no longer involved in business, because the business had significantly changed.

- $\quad$ High level of system trust - ED now had a clearly-defined hierarchical and transparent management structure. Besides, employees had opportunities to discuss and make suggestions on the business's development.

- Weak family influence via the community premise - ED currently institutionalised its pursuit for community by internal policies and practices.

- Workgroups were established, where employees gathered for both work-related and social networking.

- It was written in the company's charter that employees' voices should be sought and considered in decision making.

- High level of system trust - the business institutionalised an organisational culture through formal procedures and internal policies. This practice was seen as transparent and fair by its employees.

- Weak family influence via the connection premise - external connections were wider and numerous, oriented by market practices rather than personal closeness.

- In exploring connections with suppliers, ED continuously attempted and 
the local chamber of commerce, accesses to regional and national trade fairs, and visits organised and funded by the local government.

- High level of particularistic trust the strong connections were perceived as critical for the survival and development of the business, on which the employees relied.

WD - Continuity $\begin{aligned} & \bullet \text { Strong family influence via the } \\ & \text { continuity premise - the founder's mother } \\ & \text { financed the start-up. The founder's father } \\ & \text { brought in clients and introduced the start- }\end{aligned}$
$\begin{aligned} & \text { Highly } \\ & \text { family- } \\ & \text { influenced at }\end{aligned}$
$\begin{aligned} & \text { up to industrial fairs and professional } \\ & \text { family- }\end{aligned}$
$\begin{aligned} & \text { conferences. } \\ & \text { mature stage }\end{aligned}$
$\begin{aligned} & \text { collaboration within the business and laid } \\ & \text { down rules of mutual support, encouraging } \\ & \text { collaboration among employees. }\end{aligned}$

- $\quad$ High level of particularistic trust the chief accountant reflected, "I am the employee with the longest service record with WD. She [the founder] mentored so many of us, especially at the initial stage, based on her expertise in accounting and knowledge of this industry; we feel grateful and admire her as a trustworthy and gifted leader".

Command

- Strong family influence via the command premise - the founder always commanded exclusive dealership from suppliers, and never compromised on her stance in business negotiations.

- High level of particularistic trust the exclusive dealership enabled the firm to achieve competitive advantage over other regional competitors. Employees were confident in their leader's competence and the firm. sifted out reliable partners. Customer information was recorded and updated, and interactions with these partners were reviewed on a regular basis.

- High level of system trust -ED's connection activities were open to, and widely participated by, its non-family employees.

- Mild family influence via the continuity premise - the founder explained the rationale, "We pay attention to business continuity, not necessarily the continuity of family ownership. We welcome non-family members holding shops... When they stand up for new shops, it signals that they are confident in their capabilities and are willing to take responsibilities".

- High level of system trust transparent and fair policies on new shop launch, marketing, performance appraisal, and staff recruitment were developed. The founder's sister commented, "Operations in the company became complicated after the first few years and deserved well thoughtthrough policies and rules. Our governing logic therefore changed. My sister [the founder] and the senior management team have done a good job and worked out policies and rules tailored to this business".

- Weak family influence via the command premise - non-family members were welcomed to join the business and take administrative roles. Long-serving loyal employees were encouraged to launch new shops. The non-family shop manager reflected, "While following the general directions from headquarters and sticking to the general corporate strategy, we have a final say in our own branches".

- High level of system trust - the senior management team was mainly composed of non-family members. Executive meetings were held regularly every week. The chief account stated "... We openly discuss issues in relation to resource acquisition and distribution, branch monitoring, and new opportunities in the market".

Community $\bullet \quad$ Strong family influence via the community premise - WD pursued community through personal ties at the initial stage. The training delivered by industry specialists was available only to selected employees. Training was used as a
- Weak family influence via the community premise - WD institutionalised its community pursuit via internal policies and practices, where the aim was to create a caring, value-creating and cohesive community. 
means to build up personal relationships with key staff members.

- $\quad$ High level of particularistic trust external off-the-job training was expensive for s small business. As a result, training meant privilege, as well as the care of the founder. Those who received training showed allegiance to the firm with the leader at the helm.
- Benefiting from the initial external training, WD operationalised internal on-thejob training thereafter, which was offered to all staff members.

- WD organised business-based social gatherings to build up its community.

- High level of system trust - building up a business-employee bond through stipulating transparent policies and procedures helps the firm reap the benefit of trust. The chief accountant commented, "WD has welldesigned policies and procedures, looking after our staff members' health, wellbeing and career development...". The branch manager added, "We learn significantly from the training events. We turn out to be proficient though we know little at the starting point...".

- Weak family influence via the connection premise - WD had extensive external connections with the help from various stakeholders linked to the business. The credibility and reliability of the suppliers/customers were reviewed on a regular basis.

- High level of system trust - the founder commented, "We have connections across Xinjiang and many other provinces. For our customers and suppliers, we have internal reviewing and validating schemes ... This is the common knowledge of our staff members. They hold strong belief in the system and of course the leader, since they have tangible feelings of what is going on". 